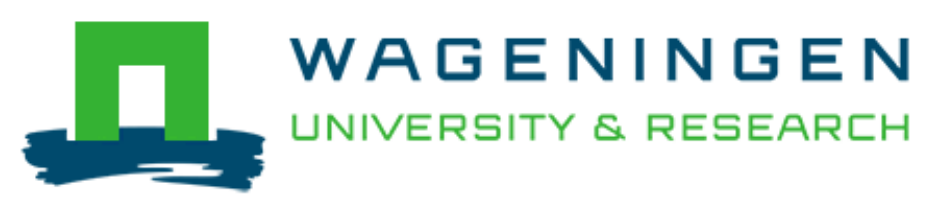

\title{
Biophysical landscape interactions: Bridging disciplines and scale with connectivity
}

van der Ploeg, M. J., Baartman, J. E. M., \& Robinson, D. A.

This article is made publically available in the institutional repository of Wageningen University and Research, under article 25fa of the Dutch Copyright Act, also known as the Amendment Taverne.

Article $25 \mathrm{fa}$ states that the author of a short scientific work funded either wholly or partially by Dutch public funds is entitled to make that work publicly available for no consideration following a reasonable period of time after the work was first published, provided that clear reference is made to the source of the first publication of the work.

For questions regarding the public availability of this article, please contact openscience.library@wur.nl.

Please cite this publication as follows:

van der Ploeg, M. J., Baartman, J. E. M., \& Robinson, D. A. (2018). Biophysical landscape interactions: Bridging disciplines and scale with connectivity. Land Degradation and Development, 29(4), 1167-1175. https://doi.org/10.1002/ldr.2820 


\title{
Biophysical landscape interactions: Bridging disciplines and scale with connectivity
}

\author{
Martine J. van der Ploeg ${ }^{1}$ (D) | Jantiene E.M. Baartman ${ }^{1}$ | David A. Robinson ${ }^{2}$
}

${ }^{1}$ Soil Physics and Land Management, Wageningen University, Wageningen, the Netherlands

${ }^{2}$ NERC - Centre for Ecology and Hydrology, Deiniol Road, Bangor LL57 2UW, UK

Correspondence

Martine J. van der Ploeg, Soil Physics and Land Management, Wageningen University, Wageningen, the Netherlands.

Email: martine.vanderploeg@wur.nl

\begin{abstract}
Landscape composition and land use impact the interactions between soil and vegetation. Differences in micro-behaviour, driven by the interplay of heterogeneous soil and vegetation dynamics, affect emergent characteristics across a landscape. Scaling approaches to understand the drivers of these emergent characteristics have been attempted, but the blueprint of interacting biophysical processes in landscapes is inherently messy and often still unknown. A complicating factor is single disciplinary focus in environmental sciences. Integrated knowledge is vital especially in view of future challenges posed by climate change, population growth, and soil threats. In this paper, we give examples of biophysical interactions that occur across various temporal and spatial scales and discuss how connectivity can be useful for bridging disciplines and scales to increase our understanding.
\end{abstract}

\section{KEYWORDS}

biophysical landscape processes, connectivity, interdisciplinary, scale

\section{1 | INTRODUCTION}

The combination of climate change, population growth, and soil threats including carbon loss, biodiversity decline, and erosion increasingly challenge the global community (Schwilch et al., 2016). A major scientific challenge in understanding processes involved in soil threats, landscape resilience, ecosystem stability, sustainable land management, and the economic consequences is that it is an interdisciplinary field (Pelletier et al., 2012), requiring more openness between scientific disciplines (Liu et al., 2007). As a result of single disciplinary focus, ambiguity arises in the understanding of landscape interactions, especially interactions between biological and physical processes in a landscape (Cook \& Hauer, 2007).

We think that integrated concepts of biophysical landscape interactions are needed to preserve ecosystem functioning in landscapes, especially in light of soil threats, population growth, climate change, and global water scarcity (Falkenmark, 1990; Schwilch et al., 2016). This requires interdisciplinary collaboration. An integrated concept can only be established by bridging the gap between several disciplines (Schulz, Seppelt, Zehe, Vogel, \& Attinger, 2006; Seppelt, Müller, Schröder, \& Volk, 2009), in a way that is appealing to those disciplines at the same time. Unfortunately, as evidence suggests, interdisciplinary work is more challenging to get funded (Bromham,
Dinnage, \& Hua, 2016). The paper discusses how interdisciplinary challenges in biophysical landscape interactions at several scales can benefit from a connectivity approach.

Biophysical landscape interactions are those biotic and abiotic processes in a landscape that have an influence on the developments within and evolution of a landscape. Examples are the impact of soil heterogeneity on promoting coexistence of microbial life in the vadose zone (Long \& Or, 2005), interaction between soil structure, hydraulics and climate and related effects of vegetation (Reinsch et al., 2017; Robinson et al., 2016), and cloud cover enhancement over forests (Teuling et al., 2017). An important aspect of biophysical landscape interactions is the different scales at which the various processes occur.

Scaling of environmental processes is possible, as long as the specific processes under consideration can be described by the same set of differential equations (Roth, 2008). Biophysical landscape interactions pose problems in this regard, because the combined physical and biochemical processes at different scales cannot be described by the same set of differential equations. For example, the description of the flow domain is scale dependent (Gelhar, 1986; Niemann \& Rovey, 2009; Sánchez-Vila, Carrera, \& Girardi, 1996). The flow domain is that part of the system that can be mathematically described with one set of equations, such as the preferential flow domain, the groundwater flow domain, and the river channel flow domain. However, in 
scaling up, these domains may coincide and therefore no longer be described by the same equations.

There are two other complicating factors in understanding biophysical landscape interactions as well. Although vegetation in many soil and hydrological models is approached physically, for example, as a sink term in many soil water models, plant biology depends on more than physics alone (e.g., Moreno de las Heras, Turnbull, \& Wainwright, 2016; Wassen, de Boer, Fleischer, Rebel, \& Dekker, 2013). And the response of vegetation to changing environmental conditions can include a possible, and often unknown, time-lag (e.g., Metzger et al., 2009). The interplay between the physical landscape and vegetation, which often coevolve, and the resulting heterogeneity and emerging patterns is the reason it is so challenging to establish a theoretical basis for describing biophysical processes in landscapes.
In view of the considerable complexity of soil, numerical modelling is widely used to understand processes in soils, however, the intricacies of biological responses in plants are mostly ignored. An integrative description for modelling biophysical interactions has been a long-standing goal in soil science (Vereecken et al., 2016). Figure 1 shows the scales involved in biophysical landscape interactions and examples of interdisciplinary challenges. In order to capture biophysical landscape interactions in models, it is important to find ways of dealing with feedbacks, the evolving heterogeneity when feedbacks play out differently, and with different scales. Interactions between ecology, hydrology, and geomorphology may be widely recognized, but they present grand challenges in themselves, especially the incorporation of feedbacks to understand system-level characteristics of landscapes.

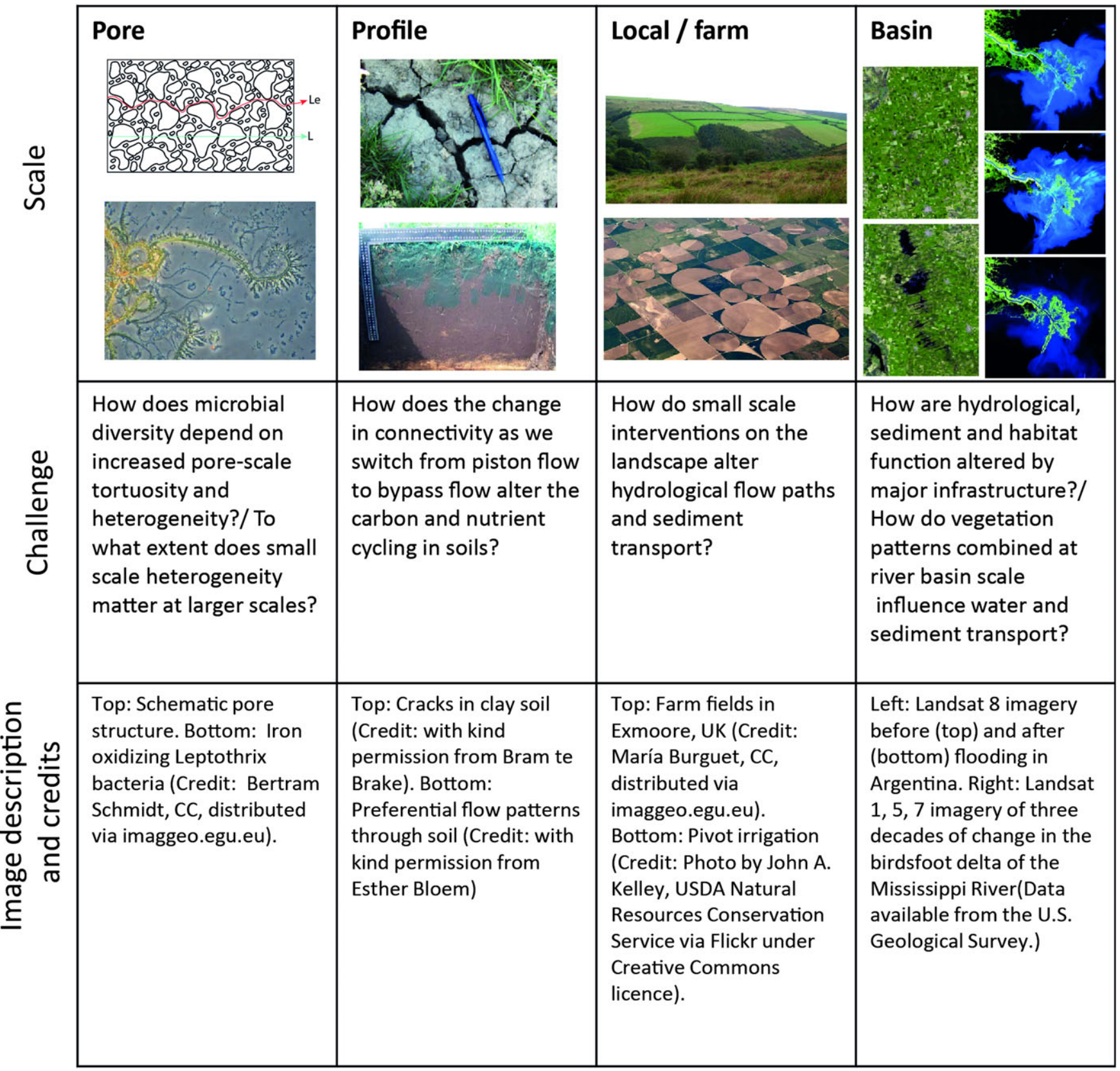

FIGURE 1 Illustration of challenges in biophysical landscape interactions where process understanding would benefit from bridging scales and disciplines [Colour figure can be viewed at wileyonlinelibrary.com] 
Many disciplines involved in environmental research acknowledge spatial structure and heterogeneity in environmental systems (e.g., Schröder \& Seppelt, 2006). Much research is focused on quantifying spatial structure and heterogeneity, such as climate variability, urban sprawl, deforestation, and habitat loss (Ahlqvist \& Shortridge, 2010). To be able to better understand the emerging patterns resulting from spatial structure and heterogeneity, connectivity has been acknowledged as a useful theoretical concept.

The concept has already been used in several (sub)disciplines: From an ecologists' perspective, connectivity describes the understanding of water-mediated transfers of matter, energy, and organisms (Pringle, 2001). Biologists often define connectivity as the degree to which a landscape facilitates or impedes the movement of individuals (Taylor, Fahrig, Henein, \& Merriam, 1993). For hydrologists, one definition is linked to how the hillslope's macropore network controls the flow through, replenishment of, and drainage from certain spots within the hillslope. This could lead to a hillslope scale connectedness of areas with relatively high hydraulic conductivity (Gomi, Sidle, Miyata, Kosugi, \& Onda, 2008). For soil scientists, connectivity may, for example, relate pore structure and effective properties for solute transport (Vogel, 2000). For geomorphologists, connectivity can be described as the physical (de)coupling of landforms (Baartman, Masselink, Keesstra, \& Temme, 2013). Finally, for sedimentologists in erosion research, connectivity relates to the transfer of sediments through a basin (Bracken \& Croke, 2007), either by wind or water movement.

This paper will apply connectivity to the challenges of integrated concepts for biophysical landscape interactions. We do this by briefly reviewing examples of (a) existing studies of biophysical interactions and (b) various scales at which these interactions take place. We then (c) introduce connectivity and outline how we think it can be used to bridge disciplines, (d) assess the connectivity concept for sustainable landscape management, and (e) address challenges across scales, including examples and ideas on how to quantify connectivity.

\section{2 | BIOPHYSICAL INTERACTIONS}

Habitat manifestation is an expression of its evolutionary history. Although the spatial distribution of habitats is largely driven by current climates and management, a soil's depth and water holding capacity will have played a role as the plant-soil system coevolves over time.

Within a landscape, microclimate and soil composition may differ, resulting in species adaptation to local conditions (Schenk \& Jackson, 2002). Plants also exhibit adaptivity depending on environmental conditions; this was shown for African savannah grasses (Hartnett, Wilson, Ott, \& Setshogo, 2013) and an alpine perennial herb (von Arx, Archer, \& Hughes, 2012). Plants may even develop habitat specific, symbiotically-conferred stress tolerance (Rodriguez, Henson, Van Volkenburgh, \& Hoy, 2008). Differences in drought sensitivity shape tree and shrub distribution in tropical forests at local and regional scales (Engelbrecht et al., 2007). Plants scan their environment biochemically, resulting in a myriad of internal information that specify its ecological niche (Trewavas, 2002).

Correlations between soil water availability and species distribution have been recognized since the last century (Schimper, 1903); and nowadays, hydrogeophysical soil mapping enables visualization of above and below ground spatial connectivity patterns (Robinson et al., 2008). It is becoming increasingly clear that root-sourced signals appear to play a key role in regulating stomatal aperture in response to soil water availability (Bacon, 2004). Constant exposure to environmental stresses, biotic or abiotic, influences plant physiology, gene adaptations, and flexibility in gene adaptation (van der Ploeg \& Teuling, 2013). Addressing gene-expression and genotype adaptations is challenging as it may complicate modelling efforts in, for example, climate change impacts, because the precise response to changing conditions is unknown (e.g, Rodriguez et al., 2008). Yet climate change is expected to lead to more spatiotemporal variability and intensity in the water cycle (e.g., Vereecken et al., 2016). Productivity and survival are therefore not only the result of a plant's genotype but also depend critically on how fast and how severe environmental conditions change (Jones, 2007). Understanding the feedbacks between environmental change and the subsequent signals and responses in a plant species is crucial for understanding the effects of environmental stresses on vegetation in landscapes.

Many of these feedbacks come together in the concept of coevolution, which is being used in the context of evolving non-linear trends in the landscape (Pelletier et al., 2013). The coevolution concept includes the change in topography or morphology of the landscape in interaction with the climate, vegetation, and hydrology. Related, catchment coevolution has been defined as the process of spatial and temporal interactions between water, energy, bedrock, sediments, carbon, ecosystems, and anthropogenic influences that leads to changes in catchment characteristics and responses (Troch et al., 2015). There is growing recognition of the importance of coevolution and biophysical interactions, which is needed to be able to better understand and sustainably manage our (natural) environment.

Pelletier et al. (2012) assessed coevolution within vegetation dynamics, pedogenesis, and topographic development in southern California using a landscape modelling approach. They found strong correlations between effective energy and mass transfer, above-ground biomass, soil thickness, hillslope-scale relief, and mean distance-to-valley. Saco and Moreno de las Heras (2013) quantified the coevolution of vegetation and topography in semiarid areas. There, non-linear interactions between physical and biological factors result in the emergence of remarkable landform related vegetation patterns such as striped and banded patterns. They found that variations in slope and abiotic or biotic factors can affect the vegetation patterns and resulting (micro)topography. Other work on coevolution includes, for example, D'Alpaos, Lanzoni, Marani, and Rinaldo (2007) who modelled the interplay of erosion, sedimentation, and vegetation dynamics in tidal embayments; Perdigão and Blöschl (2014) who investigated and quantified landscape-climate coevolution in Austria; and Jefferson, Grant, Lewis, and Lancaster (2010) who studied the coevolution of hydrology and topography in a basalt topo-chronosequence landscape in Oregon, USA.

Coevolution is increasingly incorporated into models that simulate biophysical interactions. For example, a few models have started to treat soil formation as coevolution of a large number of soil parameters (Finke \& Hutson, 2008). Other approaches include temporal changes of soil structure, a major determinant of water partitioning in the 
(sub)surface, and driver of biological activity, root growth, and soil erosion (Leij, Ghezzehei, \& Or, 2002; Stamati, Nikolaidis, Banwart, \& Blum, 2013). A few models fully incorporate interactions between physical and biological processes (e.g., Laudone et al., 2011).

\section{3 | SCALES}

Environmental and societal problems require an understanding of how processes operate at different scales, and how they can be linked across scales. Processes relevant in biophysical interactions in landscapes play a role at spatial scales ranging from millimetres to kilometres, that is, from microbiology, such as soil microorganisms, to regional groundwater flow and landscape morphology, and at temporal scales ranging from seconds, for example, earthquakes, to millennia, for example, erosion and sculpting of landscapes by glaciers.

"Scaling refers to the transfer of understanding and of quantitative results from one spatial or temporal scale to another." according to Roth (2008). Most properties in landscapes have some degree of correlation, but that depends on the scale at which observations have been made. Considering the scale at which processes occur and become visible, heterogeneity in biotic and abiotic processes is the most defining property of a landscape. Landscape heterogeneity accounts for markedly different system responses (e.g., Laudon et al., 2016). One striking example in hydrology is the emergence of scale dependency in transmissivity, which leads to an increase in effective transmissivity (or hydraulic conductivity) with an increase in observation scale (Fodor, Sándor, Orfanus, Lichner, \& Rajkai, 2011; Niemann \& Rovey, 2009; Sánchez-Vila et al., 1996; Schulze-Makuch, Carlson, Cherkauer, \& Malik, 1999).

For biophysical processes, an important factor for scaling is the soil moisture, which is dependent on soil physical properties (Robinson et al., 2016), landscape (Charpentier \& Groffman, 1992), vegetation (Mohanty \& Skaggs, 2001; Scanlon, Caylor, Levin, \& Rodriguez-Iturbe, 2007), and atmospheric conditions (Teuling, Uijlenhoet, \& Troch, 2005). Combined, these factors regulate vadose zone processes including infiltration, permeability, water holding capacity, and moisture loss rates. Techniques to monitor the resulting variables of heterogeneity become increasingly available, for example, remote sensing allows surveys covering large extents carried out at different scales (Lillesand, Kiefer, \& Chipman, 2015), and hydrogeophysics allows mapping of the subsurface (Binley et al., 2015).

Scaling in time depends largely on the time-span involved because variables of a landscape system can change status from time independent to dependent or even be irrelevant (Schumm \& Lichty, 1965). On a millennial timescale, the independent variables are, for instance, lithology, climate, and vegetation, whereas hillslope and channel morphology are dependent variables and observed discharge, and flow characteristics are considered indeterminable. Yet on a short timescale ( $<1$ year), these indeterminable variables become the dependent ones.

Additionally, there is often a time lag between an event (e.g., an extreme rainfall event, flood, or landslide) and landscape or biophysical response (Phillips, 2003; Temme \& Veldkamp, 2009). An extreme example is an earthquake, which may last only seconds, but may cause millennial-scale landscape responses, including increased erosion and catchment adjustment. In landscape ecology, time-lagged responses of biological variables to landscape modifications are widely recognized (e.g., Metzger et al., 2009). However, these are rarely considered in management plans. Understanding the ecological impacts of time-lagged responses to landscape modifications is critical for interpreting contemporary patterns of biodiversity (Royo, Stout, deCalesta, \& Pierson, 2010).

\section{4 | POTENTIAL ROLE OF CONNECTIVITY}

Connectivity is increasingly recognized as a major issue facing a hot, flat, and crowded digital society (Friedman, 2009). In economics, Didier Sornette has developed a new Dragon King theory for events that are generated by, or correspond to, changes in connectivity related mechanisms such as positive feedbacks, tipping points, bifurcations, and phase transitions. These phenomena are at the heart of connectivity and occur in non-linear and complex systems, serving to amplify Dragon King events to extreme levels, such as financial bubbles (Sornette \& von der Becke, 2011).

What does the concept of connectivity offer for a better understanding of biophysical landscape interactions across various spatial and temporal scales? The key aspect of the connectivity concept is that it can create pathways for feedbacks that are often missing in soil models. Connectivity could thus play an important role in bridging disciplines and scales (Fryirs, 2012; Okin et al., 2015; Turnbull, Wainwright, \& Brazier, 2008). Connectivity is dynamic over time and may change slowly or quickly, depending on the system and properties that are assessed. For example, connectivity in spatial landscape patterns changes slowly in response to dynamics of vegetation and soil processes, whereas connectivity changes quickly, for example, between and during rainfall events (Bracken \& Croke, 2007; Wainwright et al., 2011).

The connectivity concept is a spatially explicit approach, by inclusion of neighbourhood effects (Peters \& Herrick, 2004), and therefore calls for inclusive information on flows or fluxes that connect different spatial units. Yet connectivity has an advantage over spatially explicit modelling, where neighbourhood effects yield an increased parameter set and increased prediction uncertainty compared to nonspatial modelling. Instead, connectivity can be used to determine which spatial and temporal processes are likely to have an impact, and therefore, the resulting modelling exercise can be simplified (Paola \& Leeder, 2011). In modelling studies, the connectivity concept is illustrated by using simple models and connecting different components of the system to learn more about the processes and feedbacks, for example, for ecology (e.g., Tilman, 1994), hydrology (e.g., Porporato, D'Odorico, Laio, \& Rodriguez-Iturbe, 2003), and geomorphology (e.g., Saco, Willgoose, \& Hancock, 2007).

Quantifying connectivity is challenging, according to recent discussion with scientists within the EU network project focused on connectivity (COST1306 Action "Connecteur" http://connecteur.info/ ). Connectivity is not often directly measured, but instead, is inferred from other properties, such as soil texture distribution, moisture dynamics, or the amount of discharge or sediment. We need to develop models where connectivity becomes a major part of the formulation, and tools that allow us to measure what we need to parameterize. 
For biophysical landscape interactions, connectivity can be considered in terms of "high," "medium," and "low" for the various processes at various scales, leading to various possible (sub)systems. Subsequently, for each (sub)system a particular process under consideration can be defined in terms of its connectivity status (i.e., high, medium, or low), if it is related to other (sub)systems, and if it is relevant for the objective under investigation.

The classical example in which feedbacks between biotic and abiotic processes as well as (dis)connectivity play an important role is the vegetation patterns in semiarid landscapes, where isolated vegetation bands act as local sinks for water and nutrient flow, thereby disrupting sediment and hydrologic connectivity (e.g., Deblauwe, Couteron, Bogaert, \& Barbier, 2012). These banded patterns, consisting of alternating vegetated and bare bands, are formed because of an ecohydrological feedback system (Stewart et al., 2013). Differences in infiltration rates because of presence/absence of roots, macropores, and soil aggregation in the vegetated/bare areas (Mora \& Lázaro, 2013) lead to a runoff-runon mechanism (Saco et al., 2007). The runoff-runon mechanism is key for productivity, and disturbance of this ecohydrological feedback system can lead to severe land degradation (Moreno de las Heras, Díaz-Sierra, Nicolau, \& Zavala, 2011; Okin et al., 2009). Within this system, connectivity can be defined at several scales (see also Okin et al., 2015): (a) at the landscape scale, connectivity is low when the system is intact (Figure 2a), because flow is limited to between two vegetated bands. Flow does not, or hardly, reaches the end of the hillslope or outlet of the catchment. If the system is disrupted, connectivity on the landscape scale is significantly increased (Figure 2b) and could lead to rill or gully

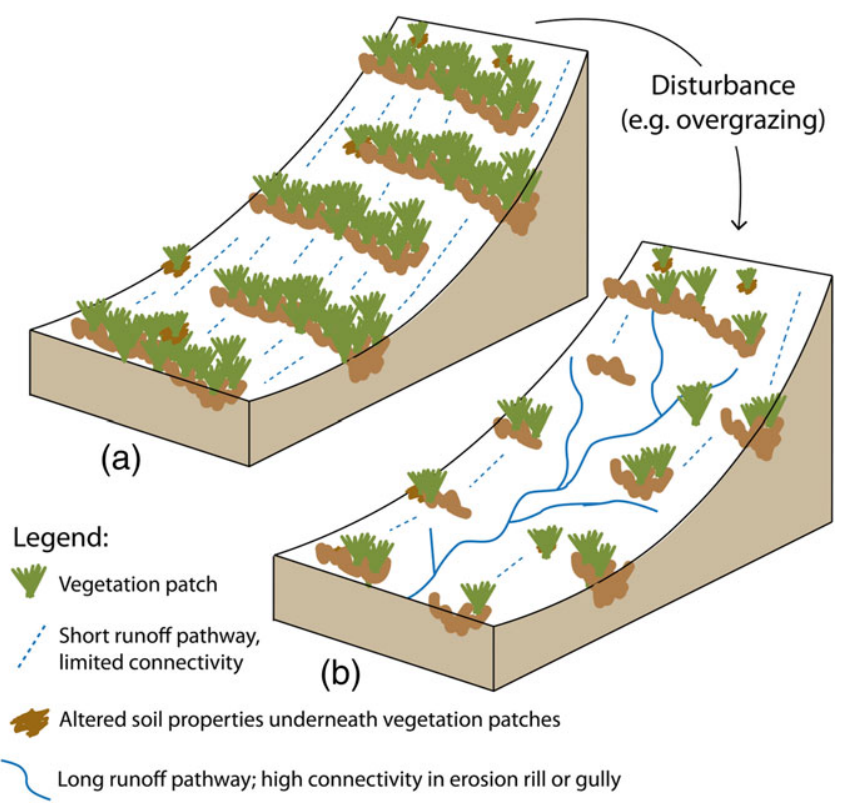

FIGURE 2 Sketch representing a dryland banded vegetation system with two potential system states: (a) intact banded system with relatively short runoff pathways and limited hydrological connectivity (dashed lines) and (b) disturbed system with longer runoff pathways and increased hydrological connectivity (continuous line) in rills or gullies [Colour figure can be viewed at wileyonlinelibrary.com] erosion. (b) At a local scale, connectivity between individual plants is medium to high: on the one hand, they compete for water, on the other hand, they help each other by providing, for example, increased organic matter underneath the plant patches (Verwijmeren et al., 2014). Finally, (c) at a micro scale, connectivity in the bare areas is relatively low because of crusting that inhibits percolation and infiltration but high in the vegetated areas because of bioturbation (Klass, Peters, Trojan, \& Thomas, 2012).

Another example where connectivity can be quantified between the various (sub)systems is the agricultural system in NW Ethiopia, (Tebebu et al., 2015; Zegeye et al., 2016) where soil erosion and sediment transfer to downstream reservoirs are an acute problem. Extensive soil and water conservation (SWC) measures have been introduced throughout the watershed to mitigate soil erosion. These measures are targeted at preventing erosion by on-field interventions such as soil bunds and grass barriers and reducing sediment transfer pathways with sediment storage dams in gullies (Mekonnen, Keesstra, Stroosnijder, Baartman, \& Maroulis, 2015). These interventions promote infiltration of precipitation into the soil and thereby reduce runoff and erosion. However, the side effect of increased infiltration is an increase in interflow from upstream to downstream parts of the catchment leading to shallower groundwater tables in the bottom of the catchment and faster saturation of the vertisols during precipitation events (Tebebu et al., 2015). Therefore, the upstream SWC measures in the hillslopes eventually promote gully formation and expansion in the valleys (Zegeye et al., 2016). In this example, connectivity can also be defined at various scales: (a) at the local scale, both the on-field (bunds and grass barrier) and between-fields (storage dams) SWC measures aim to reduce connectivity within the catchment as much as possible; however (b) at the landscape scale, this resulted in increased connectivity between the upper and lower parts of the catchments through interflow processes, enhanced by the SWC measures.

Several studies have shown the usefulness of describing biophysical landscape interactions in terms of connectivity for more humid conditions as well. For intermontane depressional wetlands, landscape (sub)surface hydrology, water chemistry, and vegetation structure were highly connected to landscape scale processes (Cook \& Hauer, 2007). Small but connected wetlands, stored more water longer, had higher productivity and different plant community composition compared to larger but isolated wetlands. At a more local scale, a wetland's ecology is determined by both frequency and duration of saturation and local groundwater quality, and species preference can thus be highly driven by microtopographical features (van der Ploeg et al., 2012). In these systems, the hydrology and vegetation are adjusted to each other. Despite such interplay between species distribution and complex patterning of ephemeral channels and streams, a relatively simple reservoir approach can capture the essence of drought and flood hazards (van der Ploeg et al., 2012). Drier conditions trigger local connections between hummocks and hollows for hydrological routing, whereas wet conditions show a connected catchment response (Oosterwoud, van der Ploeg, van der Schaaf, \& van der Zee, 2017). Emergent vegetation properties can thus also be an indication of lateral hydrologic connectivity in addition to other controls (Hwang, Band, Vose, \& Tague, 2012). 


\section{5 | CONNECTIVITY FOR SUSTAINABLE LANDSCAPE MANAGEMENT}

According to Venter et al. (2016), 75\% of all terrestrial surface is experiencing human pressure, leading to declines of natural systems and biodiversity. Hydrological connectivity in the landscape itself is often declining because of anthropogenic influences such as dams and water diversions (Pringle, 2001). However, landscapes are also increasingly connected in terms of wind erosion when desertification comes into play (Okin et al., 2009). To manage these pressures, frameworks are being proposed for incorporating ecosystem services into land management decision making (Schwilch et al., 2016). However, this remains challenging. The growing link between humans and ecosystem services necessitates a bridge between the question-driven, bioecology-centered spatial view and solution-driven, society-centered holistic view (Wu, 2006).

In this sense, connectivity can be a very useful tool to assess how resilient a landscape is to change and directs how it can be sustainably managed. For example, Jackson et al. (2013) applied connectivity in ecosystem service modelling to understand the impact of interventions like tree planting on flows of mass and energy.

\section{6 | CONNECTIVITY FOR EARTH-SYSTEM CHALLENGES}

Although connectivity is an ongoing area of research in ecology, it has yet to fully migrate into our earth system science thinking. The problems humanity faces, such as climate change, require insight into the consequences of drivers such as extreme weather events and impacts on earth systems, their management, and interventions we employ. Therefore, connectivity can be not only an interesting concept to describe emergent properties, but also a tool to evaluate management and mitigation strategies for sustainable land management (Bracken et al., 2013, Okin et al., 2009, Okin et al., 2015).

Insight into and acknowledgement of connectivity can be helpful, if not essential, for addressing key earth-system challenges, for example:

1. Natural flood management: To what extent can natural flood management alleviate flood risk? Research shows that the manipulation of the landscape at the hectare scale using shelter belts, for example, can reduce local flood risk (Marshall et al., 2009). However, the arrangement of vegetation and infrastructure features across the landscape speeds up or slows down water and sediment movement, how this scales, and how this either synchronizes or desynchronizes flows downstream remains unknown. Quantifying connectivity within the arrangement of vegetation and infrastructure features would shed light on the most optimal design and therefore the benefits of natural flood management.

2. Soil carbon and nutrient cycling: What are the feedbacks from soil to climate and how will they impact change over the next century? Soils are estimated to store three times more carbon than plants or the atmosphere (Fischlin et al., 2007), and yet the connection between soils and global circulation models remains poor (Schmidt et al., 2011). Our understanding of the links between physics and biology to impact greenhouse gas emissions from soil is also limited (Blagodatsky \& Smith, 2012; Reichstein et al., 2013). Here, connectivity could play an important role in understanding how carbon cycling is affected when soil hydraulics changes from uniform piston flow to bypass flow induced by soil water repellency.

Other challenges where connectivity concepts have already been successfully used include restoration of rivers (Jansson, Nilsson, \& Malmqvist, 2007; Reckendorfer, Baranyi, Funk, \& Schiemer, 2006). In addition, dryland communities worldwide have implicitly used connectivity for their production systems for millennia (Okin et al., 2015). The scientific challenge will be to determine when complexity is important in biophysical landscape interactions and when it can essentially be ignored in models. Only as our modelling capability and understanding of complex phenomena increases will we be able to address this challenge. Remote sensing measurement techniques, such as light detection and ranging, unmanned aerial vehicles, radar interferometry, hydrogeophysics, and analysis of optical image data, facilitate non-interfering observation of biophysical interactions on a landscape scale (e.g., Lausch et al., 2013; te Brake, Hanssen, van der Ploeg, \& de Rooij, 2013; Vogelmann, Gallanta, Shib, \& Zhub, 2016). A joint effort to connect Earth's (sub)surface processes by a combination of innovative big data-assimilation, measurement, and modelling techniques will enable the scientific community to accurately address vital issues.

\section{7 | OUTLOOK}

In this paper, we have discussed how connectivity can be used to understand and connect biophysical processes at different spatial and temporal scales, and why such a unifying concept is essential. Connectivity can bridge (sub)disciplines, although the differences in definitions and understanding need to be addressed: for example, in ecology, increased connectivity of ecosystems is seen as positive, whereas in soil science, increased connectivity in erosion is negative. We need the next generation of models to incorporate connectivity and allow for the feedbacks that make earth system infrastructure so dynamic. This calls for development of models that are less focused on detailed mechanistic understanding and more focused on networks, connectivity, and feedbacks while still incorporating the most important aspects of detailed mechanistic modelling (Paola \& Leeder, 2011). Connectivity focused models hold promise for dealing with unprecedented levels of uncertainty in future trends of climate, population dynamics, economic development, and international trade barriers.

\section{ACKNOWLEDGEMENTS}

Special thanks to those involved in the discussion on this paper: Selamawit Amare, Coleen Carranza, Bram te Brake, Karrar Mahdi, Rens Masselink, Beatriz Ramirez, Ricardo da Silva. Van der Ploeg thanks the ES1308 COST CLIMMANI for their kind support to visit the CEH in Bangor (UK). We also thank Demie Moore and two anonymous reviewers for their useful suggestions.

\section{ORCID}

Martine J. van der Ploeg (D) http://orcid.org/0000-0002-3172-7339 


\section{REFERENCES}

Ahlqvist, O., \& Shortridge, A. (2010). Spatial and semantic dimensions of landscape heterogeneity. Landscape Ecology, 25, 573-590. https://doi. org/10.1007/s10980-009-9435-8

Baartman, J. E. M., Masselink, R., Keesstra, S. D., \& Temme, A. J. A. M. (2013). Linking landscape morphological complexity and sediment connectivity. Earth Surface Processes and Landforms, 38, 1457-1471. https://doi.org/10.1002/esp.3434

Bacon, M. A. (2004). Water use efficiency in plant biology. In M. A. Bacon (Ed.), Water use efficiency in plant biology. Oxford, UK: Blackwell publishing.

Binley, A., Hubbard, S. S., Huisman, J. A., Revil, A., Robinson, D. A., Singha, K., \& Slater, L. D. (2015). The emergence of hydrogeophysics for improved understanding of subsurface processes over multiple scales. Water Resources Research, 51(6), 3837-3866. https://doi.org/ 10.1002/2015WR017016

Blagodatsky, S., \& Smith, P. (2012). Soil physics meets soil biology: Towards better mechanistic prediction of greenhouse gas emissions from soil. Soil Biology and Biochemistry, 47, 78-92. https://doi.org/10.1016/j. soilbio.2011.12.015

Bracken, L. J., \& Croke, J. (2007). The concept of hydrological connectivity and its contribution to understanding runoff-dominated geomorphic systems. Hydrological Processes, 21, 1749-1763. https://doi.org/ 10.1002/hyp.6313

Bracken, L. J., Wainwright, J., Ali, G. A., Tetzlaff, D., Smith, M. W., Reaney, S. M., \& Roy, A. G. (2013). Concepts of hydrological connectivity: Research approaches, pathways and future agendas. Earth-Science Reviews, 119, 17-34. https://doi.org/10.1016/j.earscirev.2013.02.001

Bromham, L., Dinnage, R., \& Hua, X. (2016). Interdisciplinary research has consistently lower funding success. Nature, 534, 684-687. https:// doi.org/10.1038/nature18315

Charpentier, M. A., \& Groffman, P. M. (1992). Soil moisture variability within remote sensing pixels. Journal of Geophysical Research: Atmospheres, 97(D17), 18987-18995. https://doi.org/10.1029/92JD00882

Cook, B. J., \& Hauer, F. R. (2007). Effects of hydrologic connectivity on water chemistry, soils, and vegetation structure and function in an intermontane depressional wetland landscape. Wetlands, 27(3), 719-738. https://doi.org/10.1672/0277-5212(2007)27

D'Alpaos, A., Lanzoni, S., Marani, M., \& Rinaldo, A. C. F. (2007). Landscape evolution in tidal embayments: Modeling the interplay of erosion, sedimentation, and vegetation dynamics. Journal of Geophysical Research: Earth Surface, 112, F1. https://doi.org/10.1029/2006JF000537

Deblauwe, V., Couteron, P., Bogaert, J., \& Barbier, N. (2012). Determinants and dynamics of banded vegetation pattern migration in arid climates. Ecological Monographs, 82, 3-21. https://doi.org/10.1890/11-0362.1

Engelbrecht, B. M. J., Comita, L. S., Condit, R., Kursar, T. A., Tyree, M. T., Turner, B. L., \& Hubbell, S. P. (2007). Drought sensitivity shapes species distribution patterns in tropical forests. Nature, 447. https://doi.org/ 10.1038 /nature05747

Falkenmark, M. (1990). Global water issues confronting humanity. Journal of Peace Research, 27(2), 177-190.

Finke, P. A., \& Hutson, J. L. (2008). Modelling soil genesis in calcareous loess. Geoderma, 145(3), 462-479. https://doi.org/10.1016/j. geoderma.2008.01.017

Fischlin, A., Midgley, G. F., Price, J. T., Leemans, R., Gopal, B., Turley, C., .. Velicko, A. A. (2007). Ecosystems, their properties, goods and services. In M. L. Parry, O. F. Canziani, J. P. Palutikof, P. J. van der Linden, \& C. E. Hanson (Eds.), Climate Change 2007: Impacts, adaptation and vulnerability (pp. 211-272)Cambridge Univ. Press. 2007

Fodor, N., Sándor, R., Orfanus, T., Lichner, L., \& Rajkai, K. (2011). Evaluation method dependency of measured saturated hydraulic conductivity. Geoderma, 165(1), 60-68. https://doi.org/10.1016/j. geoderma.2011.07.004

Friedman, T. L. 2009. Hot, flat, and crowded 2.0: Why we need a green revolution-And how it can renew America. Macmillan.
Fryirs, K. (2012). (Dis)Connectivity in catchment sediment cascades: A fresh look at the sediment delivery problem. Earth Surface Processes and Landforms, 38, 30-46. https://doi.org/10.1002/esp.3242View

Gelhar, L. W. (1986). Stochastic subsurface hydrology from theory to applications. Water Resources Research, 22, 9S. https://doi.org/ 10.1029/WR022i09Sp0135S

Gomi, T., Sidle, R. C., Miyata, S., Kosugi, K. I., \& Onda, Y. (2008). Dynamic runoff connectivity of overland flow on steep forested hillslopes: Scale effects and runoff transfer. Water Resources Research, 44(8). https:// doi.org/10.1029/2007WR005894

Hartnett, D. C., Wilson, G. W., Ott, J. P., \& Setshogo, M. (2013). Variation in root system traits among African semi-arid savanna grasses: Implications for drought tolerance. Austral Ecology, 38(4), 383-392. https:// doi.org/10.1111/j.1442-9993.2012.02422.x

Hwang, T., Band, L. E., Vose, J. M., \& Tague, C. (2012). Ecosystem processes at the watershed scale: Hydrologic vegetation gradient as an indicator for lateral hydrologic connectivity of headwater catchments. Water Resources Research, 48, 6. https://doi.org/10.1029/2011WR011301

Jackson, B., Pagella, T., Sinclair, F., Orellana, B., Henshaw, A., Reynolds, B., ... Eycott, A. (2013). Polyscape: A GIS mapping framework providing efficient and spatially explicit landscape-scale valuation of multiple ecosystem services. Landscape and Urban Planning, 112, 74-88. https://doi.org/10.1016/j.landurbplan.2012.12.014

Jansson, R., Nilsson, C., \& Malmqvist, B. (2007). Restoring freshwater ecosystems in riverine landscapes: The roles of connectivity and recovery processes. Freshwater Biology, 52, 589-596. https://doi.org/ 10.1111/j.1365-2427.2007.01737.x

Jefferson, A., Grant, G. E., Lewis, S. L., \& Lancaster, S. T. (2010). Coevolution of hydrology and topography on a basalt landscape in the Oregon Cascade Range, USA. Earth Surface Processes and Landforms, 35, 803-816. https://doi.org/10.1002/esp.1976

Jones, H. G. (2007). Monitoring plant and soil water status: Established and novel methods revisited and their relevance to studies of drought tolerance. Journal of Experimental Botany, 58(2), 119-130. https://doi. org/10.1093/jxb/erl118

Klass, J. R., Peters, D. P. C., Trojan, J. M., \& Thomas, S. H. (2012). Nematodes as an indicator of plant-soil interactions associated with desertification. Applied Soil Ecology, 58, 66-77. https://doi.org/ 10.1016/j.apsoil.2012.03.005

Laudon, H., Kuglerová, L., Sponseller, R. A., Futter, M., Nordin, A., Bishop, K., ... Ågren, A. M. (2016). The role of biogeochemical hotspots, landscape heterogeneity, and hydrological connectivity for minimizing forestry effects on water quality. Ambio, 45(Suppl 2), 152. https://doi. org/10.1007/s13280-015-0751-8

Laudone, G. M., Matthews, G. P., Bird, N. R. A., Whalley, W. R., Cardenas, L. M., \& Gregory, A. S. (2011). A model to predict the effects of soil structure on denitrification and $\mathrm{N}_{2} \mathrm{O}$ emission. Journal of Hydrology, 409(1), 283-290. https://doi.org/10.1016/j.jhydrol.2011.08.026

Lausch, A., Pause, M., Merbach, I., Zacharias, S., Doktor, D., Volk, M., \& Seppelt, R. (2013). A new multiscale approach for monitoring vegetation using remote sensing-based indicators in laboratory, field and landscape. Environmental Monitoring and Assessment, 185, 1215-1235. https://doi.org/10.1007/s10661-012-2627-8

Leij, F. J., Ghezzehei, T. A., \& Or, D. (2002). Modeling the dynamics of the soil pore-size distribution. Soil and Tillage Research, 64(1), 61-78. https://doi.org/10.1016/S0167-1987(01)00257-4

Lillesand, T. M., Kiefer, R. W., \& Chipman, J. W. (2015). Remote sensing and image interpretation. John Wiley \& Sons.

Liu, J., Dietz, T., Carpenter, S. R., Alberti, M., Folke, C., Moran, E., ... Taylor, W. W. (2007). Complexity of coupled human and natural systems. Science, 317(5844), 1513-1516. https://doi.org/10.1126/ science.1144004

Long, T., \& Or, D. (2005). Aquatic habitats and diffusion constraints affecting microbial coexistence in unsaturated porous media. Water Resources Research, 41, 8. https://doi.org/10.1029/2004WR003796 
Marshall, M. R., Francis, O. J., Frogbrook, Z. L., Jackson, B. M., McIntyre, N., Reynolds, B., ... Chell, J. (2009). The impact of upland land management on flooding: Results from an improved pasture hillslope. Hydrological Processes, 23(3), 464-475. https://doi.org/10.1002/hyp.7157

Mekonnen, M., Keesstra, S. D., Stroosnijder, L., Baartman, J. E. M., \& Maroulis, J. (2015). Soil conservation through sediment trapping: A review. Land Degradation \& Development, 26, 544-556. https://doi. org/10.1002/ldr.2308

Metzger, J. P., Camargo Martensen, A., Dixo, M., Bernacci, L. C., Ribeiro, M. C., Godoy Teixeira, A. M., \& Pardini, R. (2009). Time-lag in biological responses to landscape changes in a highly dynamic Atlantic forest region. Biological Conservation, 142, 1166-1177. https://doi.org/ 10.1016/j.biocon.2009.01.033

Mohanty, B. P., \& Skaggs, T. H. (2001). Spatio-temporal evolution and timestable characteristics of soil moisture within remote sensing footprints with varying soil, slope, and vegetation. Advances in Water Resources, 24(9), 1051-1067. https://doi.org/10.1016/S0309-1708(01)00034-3

Mora, J. L., \& Lázaro, R. (2013). Evidence of a threshold in soil erodibility generating differences in vegetation development and resilience between two semiarid grasslands. Journal of Arid Environments, 89 , 57-66. https://doi.org/10.1016/j.jaridenv.2012.10.005

Moreno de las Heras, M., Díaz-Sierra, R., Nicolau, J. M., \& Zavala, M. A. (2011). Evaluating restoration of man-made slopes: A threshold approach balancing vegetation and rill erosion. Earth Surface Processes and Landforms, 36, 1367-1377. https://doi.org/10.1002/esp.2160

Moreno de las Heras, M., Turnbull, L., \& Wainwright, J. (2016). Seed-bank structure and plant-recruitment conditions regulate the dynamics of a grassland-shrubland Chihuahuan ecotone. Ecology, 97(9), 2303-2318. https://doi.org/10.1002/ecy.1446

Niemann, W. L., \& Rovey, C. W. II (2009). A systematic field-based testing program of hydraulic conductivity and dispersivity over a range in scale. Hydrogeology Journal, 17(2), 307-320. https://doi.org/10.1007/ s10040-008-0365-3

Okin, G. S., Heras, M M.-d., Saco, P. M., Throop, H. L., Vivoni, E. R., Parsons, A. J., ... Peters, D. P. C. (2015). Connectivity in dryland landscapes: Shifting concepts of spatial interactions. Frontiers in Ecology and the Environment, 13, 20-27. https://doi.org/10.1890/140163

Okin, G. S., Parsons, A. J., Wainwright, J., Herrick, J. E., Bestelmeyer, B. T., Peters, D. C., \& Fredrickson, E. L. (2009). Do changes in connectivity explain desertification? Bioscience, 59, 237-244. https://doi.org/ 10.1525/bio.2009.59.3.8

Oosterwoud, M., van der Ploeg, M., van der Schaaf, S., \& van der Zee, S. (2017). Variation in hydrologic connectivity as a result of microtopography explained by discharge to catchment size relationship. Hydrological Processes, 31, 2683-2699. https://doi.org/10.1002/ hyp.11164

Paola, C., \& Leeder, M. (2011). Environmental dynamics: Simplicity versus complexity. Nature, 469, 38-39. https://doi.org/10.1038/469038a

Pelletier, J. D., Barron-Gafford, G. A., Breshears, D. D., Brooks, P. D. Chorover, J., Durcik, M., ... Troch, P. A. (2013). Coevolution of nonlinear trends in vegetation, soils, and topography with elevation and slope aspect: A case study in the sky islands of southern Arizona. Journal of Geophysical Research: Earth Surface, 118(2), 741-758. https://doi.org/ 10.1002/jgrf.20046

Pelletier, J. D., DeLong, S. B., Orem, C. A., Becerra, P., Compton, K., Gressett, K., ... Spinler, J. C. C. F. (2012). How do vegetation bands form in dry lands? Insights from numerical modeling and field studies in southern Nevada, USA. Journal of Geophysical Research: Earth Surface, 117. F04026, doi:https://doi.org/10.1029/2012JF002465

Perdigão, R. A. P., \& Blöschl, G. (2014). Spatiotemporal flood sensitivity to annual precipitation: Evidence for landscape-climate coevolution. Water Resources Research, 50, 5492-5509. https://doi.org/10.1002/ 2014WR015365

Peters, D. P. C., \& Herrick, J. E. (2004). Strategies for ecological extrapolation. Oikos, 106(3), 627-636. https://doi.org/10.1111/j.00301299.2004.12869.x
Phillips, J. D. (2003). Sources of nonlinear complexity in geomorphic systems. Progress in Physical Geography, 26, 339-361.

Porporato, A., D'Odorico, P., Laio, F., \& Rodriguez-Iturbe, I. (2003). Hydrologic controls on soil carbon and nitrogen cycles. I. Modeling scheme. Advances in Water Resources, 26(1), 45-58. https://doi.org/ 10.1016/S0309-1708(02)00094-5

Pringle, C. M. (2001). Hydrologic connectivity and the management of biological reserves: A global perspective. Ecological Applications, pp., 981-998. $\quad$ https://doi.org/10.1890/1051-0761(2001)011[0981: HCATMO]2.0.CO;2

Reckendorfer, W., Baranyi, C., Funk, A., \& Schiemer, F. (2006). Floodplain restoration by reinforcing hydrological connectivity: Expected effects on aquatic mollusc communities. Journal of Applied Ecology, 43, 474-484. https://doi.org/10.1111/j.1365-2664.2006.01155.x

Reichstein, M., Bahn, M., Ciais, P., Frank, D., Mahecha, M. D., Seneviratne, S. I., ... Papale, D. (2013). Climate extremes and the carbon cycle. Nature, 500(7462), 287-295. https://doi.org/10.1038/nature12350

Reinsch, S., Koller, E., Sowerby, A., de Dato, G., Estiarte, M., Guidolotti, G., ... Emmett, B. A. (2017). Shrubland primary production and soil respiration diverge along European climate gradient. Scientific Reports, 7, 43952. https://doi.org/10.1038/srep43952

Robinson, D. A., Abdu, H., Jones, S. B., Seyfried, M., Lebron, I., \& Knight, R. (2008). Eco-geophysical imaging of watershed-scale soil patterns links with plant community spatial patterns. Vadose Zone Journal, 7(4), 1132-1138. https://doi.org/10.2136/vzj2008.0101

Robinson, D. A., Jones, S. B., Lebron, I., Reinsch, S., Domínguez, M. T., Smith, A. R., ... Emmett, B. A. (2016). Experimental evidence for drought induced alternative stable states of soil moisture. Scientific Reports, 6. https://doi.org/10.1038/srep20018

Rodriguez, R. J., Henson, J., Van Volkenburgh, E., \& Hoy, M. (2008). Stress tolerance in plants via habitat-adapted symbiosis. ISME Journal, 2, 404-416. https://doi.org/10.1038/ismej.2007.106

Roth, K. (2008). Scaling of water flow through porous media and soils. European Journal of Soil Science, 59(1), 125-130. https://doi.org/ 10.1111/j.1365-2389.2007.00986.x

Royo, A. A., Stout, S. L., deCalesta, D. S., \& Pierson, T. G. (2010). Restoring forest herb communities through landscape-level deer herd reductions: Is recovery limited by legacy effects? Biological Conservation, 143, 2425-2434. https://doi.org/10.1016/j.biocon.2010.05.020

Saco, P. M., \& Moreno de las Heras, M. (2013). Ecogeomorphic coevolution of semiarid hillslopes: Emergence of banded and striped vegetation patterns through interaction of biotic and abiotic processes. Water Resources Research, 49, 115-126. https://doi.org/10.1029/ 2012WR012001

Saco, P. M., Willgoose, G. R., \& Hancock, G. R. (2007). Eco-geomorphology of banded vegetation patterns in arid and semi-arid regions. Hydrology and Earth System Science, 11, 1717-1730.

Sánchez-Vila, X., Carrera, J., \& Girardi, J. P. (1996). Scale effects in transmissivity. Journal of Hydrology, 183(1), 1-22. https://doi.org/10.1016/ S0022-1694(96)80031-X

Scanlon, T. M., Caylor, K. K., Levin, S. A., \& Rodriguez-Iturbe, I. (2007). Positive feedbacks promote power-law clustering of Kalahari vegetation. Nature, 449(7159), 209-212. https://doi.org/10.1038/ nature 06060

Schenk, H. J., \& Jackson, R. B. (2002). The global biogeography of roots. Ecological Monographs, 72, 311-328. https://doi.org/10.1890/00129615(2002)072[0311:TGBOR]2.0.CO;2

Schimper, A. F. W. (1903). Plant geography upon a physiological basis. Oxford: Clarendon.

Schmidt, M. W., Torn, M. S., Abiven, S., Dittmar, T., Guggenberger, G., Janssens, I. A., ... Nannipieri, P. (2011). Persistence of soil organic matter as an ecosystem property. Nature, 478(7367), 49-56. https://doi.org/ $10.1038 /$ nature10386

Schröder, B., \& Seppelt, R. (2006). Analysis of pattern-process interactions based on landscape models-overview, general concepts, and 
methodological issues. Ecological Modelling, 199(4), 505-516. https:// doi.org/10.1016/j.ecolmodel.2006.05.036

Schulz, K., Seppelt, R., Zehe, E., Vogel, H. J., \& Attinger, S. (2006). Importance of spatial structures in advancing hydrological sciences. Water Resources Research, 42. W03S03, doi:https://doi.org/10.1029/ 2005WR004301

Schulze-Makuch, D., Carlson, D. A., Cherkauer, D. S., \& Malik, P. (1999). Scale dependency of hydraulic conductivity in heterogeneous media. Ground Water, 37(6), 904-919. https://doi.org/10.1111/j.17456584.1999.tb01190.x

Schumm, S. A., \& Lichty, R. W. (1965). Time, space and causality in geomorphology. American Journal of Science, 263, 110-119. https://doi.org/ 10.2475/ajs.263.2.110

Schwilch, G., Bernet, L., Fleskens, L., Giannakis, E., Leventon, J., Marañón, T., ... Verzandvoort, S. (2016). Operationalizing ecosystem services for the mitigation of soil threats: A proposed framework. Ecological Indicators, 67, 586-597. https://doi.org/10.1016/j.ecolind.2016.03.016

Seppelt, R., Müller, F., Schröder, B., \& Volk, M. (2009). Challenges of simulating complex environmental systems at the landscape scale: $A$ controversial dialogue between two cups of espresso. Ecological Modelling, 220, 3481-3489. https://doi.org/10.1016/j.ecolmodel.2009. 09.009

Sornette, D., \& von der Becke, S. (2011). Complexity clouds finance-risk models. Nature, 471(7337), 166-166. https://doi.org/10.1038/ 471166a

Stamati, F. E., Nikolaidis, N. P., Banwart, S., \& Blum, W. E. (2013). A coupled carbon, aggregation, and structure turnover (CAST) model for topsoils. Geoderma, 211, 51-64. https://doi.org/10.1016/j. geoderma.2013.06.014

Stewart, J., Parsons, A. J., Wainwright, J., Okin, G. S., Bestelmeyer, B. T., Fredrickson, E. L., \& Schlesinger, W. H. (2013). Modeling emergent patterns of dynamic desert ecosystems. Ecological Monographs, 84, 373-410. https://doi.org/10.1890/12-1253.1

Taylor, P. D., Fahrig, L., Henein, K., \& Merriam, G. (1993). Connectivity is a vital element of landscape structure. Oikos, 571-573. https://doi.org/ $10.2307 / 3544927$

te Brake, B., Hanssen, R. F., van der Ploeg, M. J., \& de Rooij, G. H. (2013). Satellite-based radar interferometry to estimate large-scale soil water depletion from clay shrinkage: Possibilities and limitations. Vadose Zone Journal, 12, 3. https://doi.org/10.2136/vzj2012.0098

Tebebu, T. Y., Steenhuis, T. S., Dagnew, D. C., Guzman, C. D., Bayabil, H. K., Zegeye, A. D., ... Tilahun, S. A. (2015). Improving efficacy of landscape interventions in the (sub)humid Ethiopian highlands by improved understanding of runoff processes. Frontiers in Earth Science, 3, 49. https:// doi.org/10.3389/feart.2015.00049

Temme, A. J. A. M., \& Veldkamp, A. (2009). Multi-process Late Quaternary landscape evolution modelling reveals lags in climate response over small spatial scales. ESPL, 34, 573-589. https://doi.org/10.1002/ esp.1758

Teuling, A. J., Taylor, C. M., Meirink, J. F., Melsen, L. A., Miralles, D. G., van Heerwaarden, C. C., ... Vilà-Guerau de Arellano, J. (2017). Observational evidence for cloud cover enhancement over western European forests. Nature Communications, 8, 14065. https://doi.org/ 10.1038/ncomms14065

Teuling, A. J., Uijlenhoet, R., \& Troch, P. A. (2005). On bimodality in warm season soil moisture observations. Geophysical Research Letters, 32, 13. https://doi.org/10.1029/2005GL023223

Tilman, D. (1994). Competition and biodiversity in spatially structured habitats. Ecology, 75(1), 2-16. https://doi.org/10.2307/1939377

Trewavas, A. (2002). Plant intelligence: Mindless mastery. Nature, 415, 841. https://doi.org/10.1038/415841a

Troch, P. A., Lahmers, T., Meira, A., Mukherjee, R., Pedersen, J. W., Roy, T., \& Valdés-Pineda, R. (2015). Catchment coevolution: A useful framework for improving predictions of hydrological change? Water Resources Research, 51, 4903-4922. https://doi.org/10.1002/ 2015WR017032

Turnbull, L., Wainwright, J., \& Brazier, R. E. (2008). A conceptual framework for understanding semi-arid land degradation: Ecohydrological interactions across multiple-space and time scales. Ecohydrology, 1, 23-34. https://doi.org/10.1002/eco.4

van der Ploeg, M. J., Appels, W. M., Cirkel, D. G., Oosterwoud, M. R., Witte, J. P., \& Van der Zee, S. E. A. T. M. (2012). Microtopography as a driving mechanism for ecohydrological processes in shallow groundwater systems. Vadose Zone Journal, 11, 3. https://doi.org/ 10.2136/vzj2011.0098

van der Ploeg, M. J., \& Teuling, A. J. (2013). Going back to the roots: The need to link plant functional biology with vadose zone processes. Procedia Environmental Sciences, 19, 379-383. https://doi.org/ 10.1016/j.proenv.2013.06.043

Venter, O., Sanderson, E. W., Magrach, A., Allan, J. R., Beher, J., Jones, K. R., ... Watson, J. E. M. (2016). Sixteen years of change in the global terrestrial human footprint and implications for biodiversity conservation. Nature Communications, 7. https://doi.org/10.1038/ncomms12558

Vereecken, H., Schnepf, A., Hopmans, J. W., Javaux, M., Or, D., Roose, T., ... Young, I. M. (2016). Modeling soil processes: Review, key challenges, and new perspectives. Vadose Zone Journal, 15, 5. https://doi.org/ 10.2136/vzj2015.09.0131

Verwijmeren, M., Rietkerk, M., Bautista, S., Mayor, A. G., Wassen, M. J., \& Smit, C. (2014). Drought and grazing combined: Contrasting shifts in plant interactions at species pair and community level. Journal of Arid Environments, 111, 53-60. https://doi.org/10.1016/j. jaridenv.2014.08.001

Vogel, H. J. (2000). A numerical experiment on pore size, pore connectivity, water retention, permeability, and solute transport using network models. European Journal of Soil Science, 51(1), 99-105. https://doi. org/10.1046/j.1365-2389.2000.00275.x

Vogelmann, J. E., Gallanta, A. L., Shib, H., \& Zhub, Z. (2016). Perspectives on monitoring gradual change across the continuity of Landsat sensors using time-series data. Remote Sensing of Environment, 185, 258-270. https://doi.org/10.1016/j.rse.2016.02.060

von Arx, G., Archer, S. R., \& Hughes, M. K. (2012). Long-term functional plasticity in plant hydraulic architecture in response to supplemental moisture. Annals of Botany. https://doi.org/10.1093/aob/mcs030

Wainwright, J., Turnbull, L., Ibrahim, T. G., Lexartza-Artza, I., Thornton, S. F., \& Brazier, R. E. (2011). Linking environmental regimes, space and time: Interpretations of structural and functional connectivity. Geomorphology, 126, 387-404. https://doi.org/10.1016/j.geomorph.2010.07.027

Wassen, M. J., de Boer, H. J., Fleischer, K., Rebel, K. T., \& Dekker, S. C. (2013). Vegetation-mediated feedback in water, carbon, nitrogen and phosphorus cycles. Landscape Ecology, 28(4), 599-614. https://doi. org/10.1007/s10980-012-9843-z

$\mathrm{Wu}$, J. (2006). Landscape ecology, cross-disciplinarity, and sustainability science. Landscape Ecology, 21(1), 1-4. https://doi.org/10.1007/ s10980-006-7195-2

Zegeye, A. D., Langendoen, E. J., Stoof, C. R., Tilahun, S. A., Dagnew, D. C., Zimale, F. A., ... Steenhuis, T. S. (2016). Morphological dynamics of gully systems in the subhumid Ethiopian Highlands: the Debre Mawi watershed. The Soil, 2, 443-458.

How to cite this article: van der Ploeg MJ, Baartman JEM, Robinson DA. Biophysical landscape interactions: Bridging disciplines and scale with connectivity. Land Degrad Dev. 2018;29:1167-1175. https://doi.org/10.1002/ldr.2820 